\title{
CITIZEN SCIENCE AND ASIAN TIGER MOSQUITO: A PILOT STUDY ON PROCIDA ISLAND, A POSSIBLE MEDITERRANEAN SITE FOR MOSQUITO INTEGRATED VECTOR MANAGEMENT TRIALS
}

\author{
V. PETRELLA ${ }^{1}$, G. SACCONE ${ }^{1}$, G. LANGELLA ${ }^{2,3}$, B. CAPUTO ${ }^{4}$, \\ M. MANICA ${ }^{4,5}$, F. FILIPPONI ${ }^{4}$, A. DELLA TORRE ${ }^{4}$ AND \\ M. SALVEMINI ${ }^{1}$ \\ ${ }^{1}$ Department of Biology, University of Naples Federico II, Italy; \\ marco.salvemini@unina.it \\ ${ }^{2}$ National Research Council, Institute for Agricultural and Forest Systems in the \\ Mediterranean (ISAFoM), Italy \\ ${ }^{3}$ Department of Agricultural Sciences, University of Naples Federico II, Italy \\ ${ }^{4}$ Department of Public Health and Infectious Diseases, University of Rome La \\ Sapienza, Italy \\ ${ }^{5}$ Department of Biodiversity and Molecular Ecology, Edmund Mach Foundation, \\ San Michele all'Adige, Italy
}

\begin{abstract}
SUMMARY
During the past twenty years, the number of research projects involving people not trained as scientists, the so-called citizen science, has increased consistently, including mosquito monitoring and control projects. The involvement of citizens in mosquito monitoring programmes not only helps scientists during the data collection phase, but also raises public awareness on mosquito-transmitted diseases and educates citizens about virtuous behaviours that can help in reducing mosquito populations and their spread. The Asian tiger mosquito Aedes albopictus (Skuse) is an invasive species that became established in Europe starting in 1979, with Italy representing currently one of the most infested countries. Procida, a small Mediterranean island in the Naples gulf (Campania region, southern Italy) has unique and very interesting features facilitating the field testing of mosquito integrated vector management (IVM) approaches and control methods, including the Sterile Insect Technique (SIT). With the help of the local municipal administration, the Procida citizens are actively involved as volunteers in monitoring the seasonal and spatial distribution of the Asian tiger mosquito. The collected baseline data will be useful to implement a future island-wide integrated suppression trial of Ae. albopictus, including the release of sterile males, to be carried out in collaboration with the local municipal administration and with the technical support of the Joint FAO/IAEA Division in Vienna.
\end{abstract}

J. Hendrichs, R. Pereira and M. J. B. Vreysen (eds.), Area-Wide Integrated Pest Management: Development and Field Application, pp. 729-745. CRC Press, Boca Raton, Florida, USA. (C) 2021 IAEA 
Key Words: Baseline data, mosquito surveillance, Aedes albopictus, Culex pipiens, Culex laticinctus, IVM, SIT, Sterile Insect Technique, Italy

\section{INTRODUCTION}

According to the World Health Organization (WHO), mosquitoes are considered the deadliest animals on Earth, causing more than one million human deaths every year and representing a risk due to the diseases they transmit, and to which more than one third of the human population is exposed (WHO 2019).

In this scenario, during the last four decades, invasive mosquito species have played a significant role because of their confirmed or potential capabilities to vector an increasing number of diseases to humans and animals. Introductions of invasive mosquito species have increased world-wide as a result of the globalisation of trade and travel, climate change, and the capacity of the mosquitoes to adapt from their native areas to temperate regions, such as the European continent.

Among all the invasive mosquito species listed to date, Aedes species are of major concern, with at least five described species having become established in parts of Europe (Medlock et al. 2015). This includes the Asian tiger mosquito Aedes albopictus (Skuse 1894) (Diptera: Culicidae) that is considered a major threat to public health in Europe.

\subsection{Aedes albopictus Invades Europe}

Ae. albopictus originated from Southeast Asia and has spread world-wide during the last 40 years. In Europe, it was firstly recorded in Albania in 1979 and is present today in 24 European countries (ECDC 2018a). Species distribution models, combining eco-environmental and terrestrial cover variables, and future climatic scenarios, predict further spread of this species in Europe and other countries in the world (Fischer et al. 2011; Caminade et al. 2012; Cunze et al. 2016).

In Italy, the mosquito arrived in 1990 in Genova (Liguria region) (Sabatini et al. 1990) and has quickly spread over the whole Italian territory, in particular in the north-eastern area (Friuli-Venezia-Giulia region, and large parts of the Lombardia, Veneto and Emilia Romagna regions) and central and southern coastal areas, including major islands (Albieri et al. 2010; Marini et al. 2010; Valerio et al. 2010). Ae. albopictus has a very aggressive day-time human-biting behaviour (Valerio et al. 2010; Manica et al. 2016) and it is a competent vector for more than 20 arboviruses, including the dengue and chikungunya viruses, in addition to filarial nematodes of veterinary and zoonotic significance (Cancrini et al. 2003; Pietrobelli 2008; Bonizzoni et al. 2012). 
The first European outbreak of chikungunya fever occurred in Italy in 2007 and was ascribed to the presence of the local Ae. albopictus populations. This event drastically increased awareness of the risk of new or re-emerging mosquitoborne diseases in Europe (Gasperi et al. 2012). In addition, the Zika virus (ZIKV) outbreak in South and North America starting in 2015, and the confirmation that Ae. albopictus is a competent vector of the disease (Grard et al. 2014; Di Luca et al. 2016; Heitmann et al. 2017), have further emphasised the importance to carefully monitor and sustainably manage this species also in European countries. During the summer of 2017, about 250 cases of chikungunya fever were reported in the urban and costal area of Lazio (Venturi et al. 2017).

In the Mediterranean region, this species is mainly active during the summer, and evidence has been collected that under specific climate conditions the populations show a bimodal distribution with peaks in July and September (Manica et al. 2016). Considering the heavy nuisance caused by the Ae. albopictus female day-time biting behaviour, the presence of this species is considered also a serious socio-economic threat for regions with a tourism-based economy (Roiz et al. 2008).

To face the increasing risk of the spread of vector-borne diseases, several European Union (EU) countries started mosquito monitoring, surveillance and control programmes and, in 2005, the European Centre for Disease Prevention and Control (ECDC) was established, i.e. an EU agency aimed at strengthening Europe's defences against infectious diseases, including vector-borne diseases (Zeller et al. 2013; ECDC 2018b).

Mosquito monitoring programmes usually are based on the use of special traps (ovitraps to collect mosquito eggs, gravitraps to collect gravid female mosquitoes, and adult traps to collect adult mosquitoes of both sexes) to determine the occurrence and the spatial-temporal distribution of the species. However, the management of an area-wide trap network, covering wide territories or a whole country, requires great financial resources as well as a significant labour force.

\subsection{Involvement of Civil Society in Citizen Science}

Recently, the involvement of civil society in research projects, also known as citizen science, has become increasingly popular (Dickinson et al. 2012; Bonney et al. 2014). To support mosquito monitoring performed by experts through conventional trapping (the so called "active" monitoring), community-based surveillance activities have been launched in some EU countries. These citizen science projects are based on the public participation through active monitoring, such as the "Mosquito Atlas" in Germany (Mückenatlas 2019) and the "Mosquito Recording Scheme" (MRS 2019) in the UK, or through smartphone-based mosquito data collection applications (the so called "passive" monitoring), such as the "Mosquito Radar" (Muggenradar 2019) in the Netherlands, the "Mosquito 
Alert" (2019) (hunting the tiger) in Spain, the "iMoustique ${ }^{\circledR}$ " in France, the "MosquitoWEB" (2019) in Portugal, and the ZanzaMapp (2019) in Italy.

The results of some of these projects, recently reviewed by Kampen and colleagues, demonstrated that public mosquito surveillance, despite some limitations mainly represented by the inexperience of volunteers, can usefully supplement surveillance programmes by:

1. Substantially reducing the field work costs

2. Collecting data in such a quantity that conventional research groups would not be able to generate by themselves

3. Raising awareness and improving knowledge amongst citizens on invasive species and associated public health problems

4. Detecting the arrival and the spread of Ae. albopictus and other invasive mosquito species populations in various European areas (Kampen et al. 2015).

Hence, such citizen science projects can help public agencies with the monitoring and control efforts of invasive mosquito species (Jordan et al. 2017; Palmer at al. 2017).

Mosquito management activities are frequently ineffective because some mosquito species, as is the case of Ae. albopictus, breed in human-made water containers, mostly located within private-access properties and areas, making the required action within the target area (egg or adult monitoring, sanitization and control of larval breeding sites, etc.) very complex, if not impossible, to be achieved. A mosquito community-based monitoring network could facilitate the monitoring on such private properties, and also help in the successive implementation of area-wide mosquito population suppression programmes that can include eco-friendly approaches such as the Sterile Insect Technique (SIT) or the Incompatible Insect Technique (IIT).

The SIT, which is based on the mass-rearing and release of sterile male-only insects that induce sterility in the local population, has been successfully applied against the New World screwworm fly and several fruit flies, tsetse flies, and lepidopteran species (Dyck et al. 2021).

The IIT is an alternative population suppression strategy, based on cytoplasmic incompatibility (CI), widespread in many diplodiploid species. With IIT the sterility in the target population is achieved through the release and mating of males infected with a different Wolbachia strain, which results in embryonic lethality (Saridaki and Bourtzis 2010; Lees et al. 2015).

The absence of effective vaccines against mosquito-borne diseases and the problem of growing insecticide resistance in mosquito populations (Sokhna et al. 2013; Vontas et al. 2012) have made the SIT, the IIT, and related approaches potentially promising components of area-wide integrated vector management (AW-IVM) programmes for some key mosquito species (Lees et al. 2015; Bourtzis et al. 2016). 
Ae. albopictus is a suitable candidate species for SIT and/or IIT application because of its relative ease of mass-rearing, its sexual dimorphism that facilitates sex separation, and its low biological dispersal potential (Bellini et al. 2007, 2013; Albieri et al. 2010; Marini et al. 2010; Balestrino et al. 2014; Gilles et al. 2014).

In this paper, we present a community-based mosquito monitoring approach that we are developing on Procida, a Mediterranean island in southern Italy. We are collecting, with citizen involvement, baseline data and setting-up the optimal social and technical working environment for future Ae. albopictus population suppression experiments by the SIT and/or the IIT (Bourtzis et al. 2016).

\section{PROCIDA ISLAND}

Procida is a small island of the Phlegraean archipelago, situated in the Naples gulf, about three $\mathrm{km}$ from both the mainland and Ischia Island. It is a flat volcanic island (average $27 \mathrm{~m}$ above sea level) with a $16 \mathrm{~km}$-long jagged coastline which forms four capes and with a total surface area of only $4.1 \mathrm{~km}^{2}$, including the uninhabited tiny satellite island of Vivara $\left(0.4 \mathrm{~km}^{2}\right)$. Except for Vivara, which is a natural reserve, Procida's territory is quite urbanized and accessible.

Most of Procida's private properties include a garden with ornamental flowers, vegetable cultivations and/or orchards with citrus plants and family-type farming of chickens and rabbits. Despite its small surface, Procida has a very high and urban-like population density with 10.477 inhabitants (2459 inhabitants $/ \mathrm{km}^{2}$ - ISTAT 28/02/2017). This human population density approximately doubles during the summer months, because of tourism, which is the current main local economic activity.

According to the perception of residents, Ae. albopictus arrived on the island around the year 2000, most probably introduced by tourists and/or maritime transport of goods. Thanks to very favourable host and climatic conditions, with an average annual temperature of $16.2^{\circ} \mathrm{C}$ and an average annual precipitation of $797 \mathrm{~mm}$ (http://bit.ly/ecdata procida; accessed: 07 abundant availability of water containers in private gardens, Ae. albopictus spread quickly over the entire island, reaching high population densities in some areas and becoming a serious nuisance in the last years.

Procida has unique and very interesting features for field testing of mosquito IVM including the SIT or the IIT: a very small size, a completely urbanized and accessible territory, a high human population density and year-round presence of Ae. albopictus. The island has obtained a world-famous reputation, due to several novels and films that were set there, which could help provide wide media coverage in the case of very positive population suppression results, that could facilitate fundraising for future larger population control tests.

Furthermore, many Procida citizens are aware of the SIT approach and of its advantages and effectiveness in insect pest control programmes. In fact, during the 1970's and 1980's, Procida island was chosen as an experimental area to study 
the field performance of sterilized male Mediterranean fruit fly Ceratitis capitata from a genetic sexing strain (Robinson 2002) in a cooperative programme between the Italian National Committee for Research and Development of Nuclear Energy (ENEA) and the International Atomic Energy Agency (IAEA) (Cirio 1975; Cirio et al. 1987). About 20 million sterile Mediterranean fruit fly males were released on the island from April to July 1986 and the population suppression obtained, linked with the protection of citrus fruits, was positively perceived by the residents for several years thereafter.

\section{FIRST RECORD OF Aedes albopictus ON PROCIDA ISLAND}

Official data about Asian tiger mosquito presence in the Phlegraean islands (islands in the Gulf of Naples and the Campania region of southern Italy) are available only for the satellite island of Vivara, where Ae. albopictus was detected for the first time in 2002 (D'Antonio and Zeccolella 2007).

In September 2015, an entomological field survey was undertaken in five private properties and five tourist facilities to confirm the presence of Ae. albopictus on Procida island and to obtain preliminary data about its distribution (Fig. 1A).

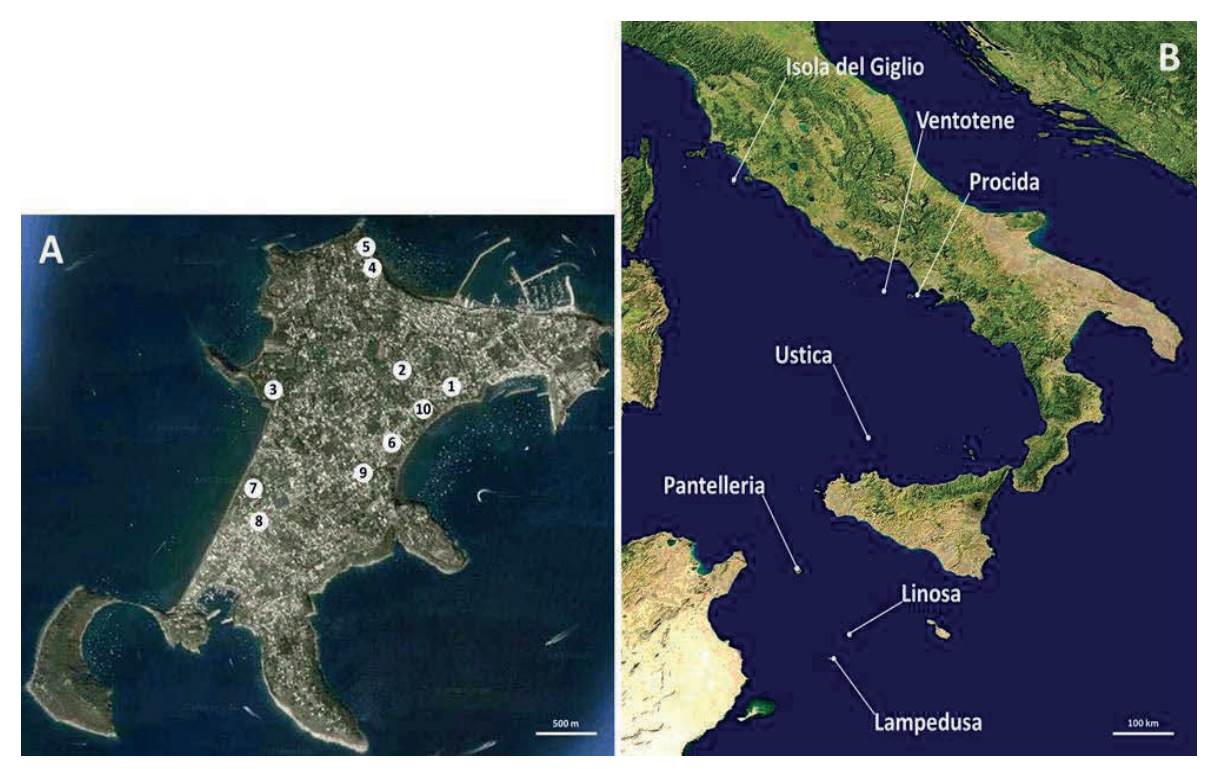

Figure 1. A) Aedes albopictus field sampling sites on Procida island in 1-3 September 2015. Locations 1-10 are listed in Table 1. B) Italian minor islands were the presence of Ae. albopictus has been officially reported. 
Modified CDC light traps (CDC-LT) were used for the field sampling (Reisen et al. 2000; Li et al. 2016), without standard light source and baited with dry ice. CDCLTs were placed in shaded locations in courtyards of private houses with rich vegetation for three days, in the period 1-3 September $2015\left(26.3^{\circ} \mathrm{C}\right.$ average temperature, $75 \%$ average humidity, $7.6 \mathrm{~km} / \mathrm{h}$ average wind speed). Traps were activated each day from $8.00 \mathrm{~h}$ till $20.00 \mathrm{~h}$. Deployment and inspection of the CDCLTs were hampered by the frequent bites of Ae. albopictus to the trap operators.

A total of 240 adult mosquitoes were collected in eight out of 10 CDC-LTs. Adult Aedes mosquito specimens were identified using morphological characteristics (Schaffner et al. 2001) and a summary of the number and sex of Ae. albopictus trapped at each site is given in Table 1. A total of 216 Ae. albopictus adults were sampled (169 females and 47 males) with the remaining 24 mosquitoes identified as males and females of Culex pipiens L. and Culex laticinctus Edwards (Di Marco and Severini, unpublished results).

Table 1. Aedes albopictus sampled with CDC-LTs in 1-3 September 2015 on Procida island

\begin{tabular}{|c|c|c|c|c|c|c|}
\hline $\begin{array}{l}\text { Trap } \\
\text { No. }\end{array}$ & $\begin{array}{l}\text { Site } \\
\text { Name }\end{array}$ & $\begin{array}{c}\text { Coord. } \\
\text { N. }\end{array}$ & $\begin{array}{l}\text { Coord. } \\
\text { E. }\end{array}$ & $\begin{array}{c}\text { Aedes } \\
\text { albopictus } \\
\text { males }\end{array}$ & $\begin{array}{c}\text { Aedes } \\
\text { albopictus } \\
\text { females }\end{array}$ & $\begin{array}{c}\text { Other } \\
\text { Mosquitoes* }\end{array}$ \\
\hline 1 & $\begin{array}{l}\text { Edificio } \\
\text { Scolastico }\end{array}$ & $\begin{array}{l}40^{\circ} 45^{\prime} \\
39.1^{\prime \prime}\end{array}$ & $\begin{array}{l}14^{\circ} 01^{\prime} \\
27.8^{\prime \prime}\end{array}$ & 3 & 68 & 22 \\
\hline 2 & $\begin{array}{l}\text { Madonna } \\
\text { della } \\
\text { Libera }\end{array}$ & $\begin{array}{l}40^{\circ} 45^{\prime} \\
43.1 "\end{array}$ & $\begin{array}{l}14^{\circ} 01^{\prime} \\
13.1^{\prime \prime}\end{array}$ & 2 & 7 & 0 \\
\hline 3 & $\begin{array}{l}\text { Camping } \\
\text { Punta } \\
\text { Serra } \\
\end{array}$ & $\begin{array}{l}40^{\circ} 45^{\prime} \\
38.6^{\prime \prime}\end{array}$ & $\begin{array}{l}14^{\circ} 00^{\prime} \\
36.3^{\prime \prime}\end{array}$ & 0 & 0 & 0 \\
\hline 4 & $\begin{array}{l}\text { Tirreno } \\
\text { Residence }\end{array}$ & $\begin{array}{l}40^{\circ} 46^{\prime} \\
05.1^{\prime \prime}\end{array}$ & $\begin{array}{l}14^{\circ} 01^{\prime} \\
03.7^{\prime \prime}\end{array}$ & 1 & 15 & 1 \\
\hline 5 & Via Faro & $\begin{array}{l}40^{\circ} 46^{\prime} \\
09.0^{\prime \prime}\end{array}$ & $\begin{array}{l}14^{\circ} 01^{\prime} \\
03.0^{\prime \prime}\end{array}$ & 1 & 2 & 0 \\
\hline 6 & Olmo & $\begin{array}{r}40^{\circ} 45^{\prime} \\
27.0^{\prime \prime} \\
\end{array}$ & $\begin{array}{l}14^{\circ} 01^{\prime} \\
10.3^{\prime \prime}\end{array}$ & 37 & 48 & 0 \\
\hline 7 & $\begin{array}{l}\text { Chiaio- } \\
\text { lella }\end{array}$ & $\begin{array}{l}40^{\circ} 45^{\prime} \\
17.5^{\prime \prime}\end{array}$ & $\begin{array}{l}14^{\circ} 00^{\prime} \\
30.7^{\prime \prime}\end{array}$ & 0 & 3 & 1 \\
\hline 8 & $\begin{array}{l}\text { Hotel } \\
\text { Riviera }\end{array}$ & $\begin{array}{l}40^{\circ} 45^{\prime} \\
10.9^{\prime \prime}\end{array}$ & $\begin{array}{l}14^{\circ} 00^{\prime} \\
32.3^{\prime \prime}\end{array}$ & 2 & 19 & 0 \\
\hline 9 & $\begin{array}{l}\text { Camping } \\
\text { Vivara }\end{array}$ & $\begin{array}{l}40^{\circ} 45^{\prime} \\
21.2^{\prime \prime}\end{array}$ & $\begin{array}{l}14^{\circ} 01^{\prime} \\
02.2^{\prime \prime}\end{array}$ & 0 & 0 & 0 \\
\hline \multirow[t]{2}{*}{10} & $\begin{array}{l}\text { Via dei } \\
\text { Bagni }\end{array}$ & $\begin{array}{l}40^{\circ} 45^{\prime} \\
34.3^{\prime \prime}\end{array}$ & $\begin{array}{l}14^{\circ} 01^{\prime} \\
19.0^{\prime \prime}\end{array}$ & 1 & 7 & 0 \\
\hline & & & Total & 47 & 169 & 24 \\
\hline
\end{tabular}

${ }^{*}$ Culex pipiens $L$. and Culex laticinctus 
Trap site number 6, named "Olmo", represents an interesting hot spot of Ae. albopictus density as well as a "prototype" of the typical family-type garden on Procida island. This site is comprised of a 0.09 ha garden with cultivation of vegetables and farming of chickens and rabbits. In this garden three big water containers were identified that were utilized for the irrigation of the vegetables. The containers contained hundreds of mosquito larvae of various developmental stages and pupae.

Larvae and pupae were collected, transported alive to the laboratory at Department of Biology, University of Naples Federico II, and reared until adulthood resulting in 57 males and 118 females of Ae. albopictus.

Our Ae. albopictus record represents the first official report of this species on Procida island and these data are added to the recent record of the occurrence of the Asian tiger mosquito on other six Italian minor islands: Isola del Giglio (Toscana), Ventotene (Lazio), and Ustica, Lampedusa, Linosa and Pantelleria (Sicilia) (Fig. 1B) (Romi et al. 2016; Toma et al. 2017).

Other Mediterranean islands with reported presence of Ae. albopictus mosquitoes are the Maltese islands (Gatt et al. 2009) and the Balearic Islands of Mallorca, Ibiza and Minorca (Spain) (Miquel et al. 2013; Barceló et al. 2015; Bengoa et al. 2016).

\section{THE PUBLIC SURVEY ON PROCIDA ISLAND OF THE MOSQUITO PROBLEM}

During the entomological survey on Procida Island in September 2015, a public survey was likewise conducted to evaluate the perception by Procida inhabitants of the Asian tiger mosquito problem and their interest to support and to participate in area-wide programmes to control this insect. The public survey was a crucial step to start informing citizens about our project and to create the first positive relationship with local people interested and sensitive to the mosquito problem.

We interviewed, using a paper-based questionnaire, 200 randomly selected people (about $2 \%$ of the total island population; see Table 2). We obtained a very high participation rate with 200 out of 213 people who accepted to participate in our survey (94\%). A list of the questions of the survey and their responses is reported in Table 3.

According to $70 \%$ of respondents, the abundance and hence the problem of mosquitoes in Procida has increased in the past 10 years. Most inhabitants spend on average more than one hour a day in green areas or outdoors, and about $50 \%$ of respondents were forced to limit the time spent outdoor activities because of the mosquitoes. Seventy-seven percent of respondents were aware of the nature of mosquitoes as human disease vectors and about a quarter of respondents know people who needed medical assistance because of a mosquito bite. Eighty five percent of respondents attempted to limit mosquito bites using electric diffusers, mosquito nets or chemical repellents. 
Table 2. Sample classification from the survey of Procida inhabitants on the Asian tiger mosquito problem

\begin{tabular}{|c|c|c|c|c|}
\hline \multicolumn{5}{|c|}{ Survey sample characteristics $(N=200)$} \\
\hline \multirow[t]{2}{*}{ Gender } & Male & \multicolumn{3}{|l|}{ Female } \\
\hline & 103 & \multicolumn{3}{|l|}{97} \\
\hline \multirow[t]{2}{*}{ Residence } & Local resident & \multicolumn{3}{|l|}{ Tourist } \\
\hline & 171 & \multicolumn{3}{|l|}{29} \\
\hline \multirow[t]{2}{*}{ Age } & 18-39 years & 40-64 years & \multicolumn{2}{|c|}{$64+$ years } \\
\hline & 85 & 90 & \multicolumn{2}{|l|}{25} \\
\hline \multirow[t]{2}{*}{ Occupation } & Unemployed & Employed & Retired & Student \\
\hline & 40 & 120 & 26 & 14 \\
\hline
\end{tabular}

By contrast, very few respondents make active efforts to curtail the proliferation of these insects through the reduction of larval breeding sites (only $3 \%$ of respondents use larvicide products to dissolve in water and only $11 \%$ remove water containers from their houses or gardens).

Eighty eight percent of respondents were in favour of a mosquito control programme on Procida, although only $44 \%$ of people surveyed agreed to the installation of monitoring traps on their private properties. A third of respondents agreed to contribute economically to the project, and $25 \%$ of respondents would be interested to commit themselves as volunteers to the realization of the project (contributing from one to 24 hours per week).

\section{THE PROCIDA COMMUNITY-BASED APPROACH}

Considering the specific features of Procida island and the positive response from locally interviewed inhabitants and tourists, in 2016 we decided to start an Ae. albopictus systematic monitoring project, involving the local municipal administration and citizens, with the aim to collect baseline data to fully characterize the Procida site for a future SIT-based area-wide suppression programme.

We developed a multi-step approach plan, to progressively increase the citizen and administrator participation in the project, which includes three main phases:

- Phase 1: Monitoring over one year using ovitraps to define the temporal dynamic of the Ae. albopictus population on the island.

- Phase 2: Higher-density ovitrap monitoring to capture the spatial distribution of the mosquito on the island, possibly identifying hot spots.

- Phase 3: Estimation of local mosquito population density by mark-releaserecapture (MRR) experiments. 
Table 3. Responses to survey questions on the Asian tiger mosquito problem by Procida inhabitants

\begin{tabular}{|c|c|c|c|c|}
\hline Survey question & \multicolumn{4}{|c|}{ Responses (percentages) } \\
\hline \multirow{2}{*}{$\begin{array}{l}\text { 1. Over the past decade, the mosquito problem in } \\
\text { Procida has: }\end{array}$} & increased & decreased & the same & don't know \\
\hline & 70.5 & 2.0 & 15.5 & 12.0 \\
\hline \multirow[t]{2}{*}{ 2. Is there a garden or green area in your estate? } & Yes & No & & \\
\hline & 77.5 & 22.5 & & \\
\hline \multirow[t]{2}{*}{ 3. In your estate the presence of mosquitoes is: } & abundant & medium & scarce & absent \\
\hline & 35.0 & 44.5 & 17.0 & 3.5 \\
\hline \multirow[t]{3}{*}{$\begin{array}{l}\text { 4. How much time do you spend on average } \\
\text { every day in a green area/garden? }\end{array}$} & $<1$ hour & $>1$ hour & no time & \\
\hline & 18.0 & 71.5 & 10.5 & \\
\hline & Yes & No & & \\
\hline $\begin{array}{l}\text { 5. During summer, are you forced to give up } \\
\text { outdoor activities because of the mosquitoes? }\end{array}$ & 50.5 & 49.5 & & \\
\hline $\begin{array}{l}\text { 6. Did It happen that you or any of your relatives } \\
\text { and/or friends had to go to the doctor for a } \\
\text { mosquito bite? }\end{array}$ & 75.0 & 25.0 & & \\
\hline $\begin{array}{l}\text { 7. Do you know that the Asian tiger mosquito can } \\
\text { transmit viral diseases to humans? }\end{array}$ & 76.5 & 23.5 & & \\
\hline $\begin{array}{l}\text { 8. Do you use protective measures against } \\
\text { mosquitoes? }\end{array}$ & 84.5 & 15.5 & & \\
\hline 8a. Do you use electric diffusers? & 57.5 & 42.5 & & \\
\hline 8b. Do you remove standing water? & 10.5 & 89.5 & & \\
\hline 8c. Do you use mosquito nets? & 53.5 & 46.5 & & \\
\hline 8d. Do you use larvicides? & 3.0 & 97.0 & & \\
\hline 8e. Do you use insect repellents? & 44.5 & 55.5 & & \\
\hline $\begin{array}{l}\text { 9. Would you welcome a regional/municipal } \\
\text { mosquito control programme? }\end{array}$ & 88.0 & 12.0 & & \\
\hline $\begin{array}{l}\text { 10. Would you agree to the installation in your } \\
\text { property of traps for the capture and monitoring } \\
\text { of mosquitoes? }\end{array}$ & 43.5 & 56.5 & & \\
\hline $\begin{array}{l}\text { 11. Would you agree to contribute personally to } \\
\text { the financing of a mosquito control project? }\end{array}$ & 33.0 & 67.0 & & \\
\hline $\begin{array}{l}\text { 12. Are you interested in participating, as a } \\
\text { volunteer, to a mosquito monitoring and control } \\
\text { programme in Procida? }\end{array}$ & 25.0 & 75.0 & & \\
\hline
\end{tabular}

Following a numbered list of planned steps to be carried out, the main results obtained to date are: 
1. Contact with local administration: Consultations with the Procida major and municipal counsellors to explain the various aspects of the project and to request logistic support from the Procida municipal administration.

2. Information campaign: Implemented on the island by the distribution of pamphlets to inform Procida citizen about the project and to invite them to participate.

3. Active mosquito monitoring by citizens - 1: A public assembly was organized in collaboration with the Procida municipal administration to select volunteers for the first project phase. Twelve persons, including the major and two municipal counsellors were involved as volunteers in the ovitrap monitoring programme (April 2016-May 2017). These volunteers were trained over a one-week period after which they managed 16 out of 26 ovitraps autonomously over 13 months, reporting weekly mosquito collections (Fig. 2). During the 13 months of monitoring, a total of 44245 Ae. albopictus eggs were collected that were subsequently transported to the Department of Biology of the University of Naples Federico II for counting and species identification.

4. Media coverage: In collaboration with the press office of the Procida municipal administration press releases about the project were issued. (http://bit.ly/press_release1; http://bit.ly/press_release2; http://bit.ly/press_release3; http://bit.ly/press_release4; http://bit.ly/press_release5).

5. Official agreement between institutions: An official memorandum of understanding (MoU) was signed between the Procida municipal administration and the Department of Biology of the University of Naples Federico II for the implementation of the project on the island.

6. Crowdfunding campaign: A crowdfunding campaign was launched to collect funds and to further diffuse the project between Procida inhabitants (http://bit.ly/crowdfunding_procida).

7. Active mosquito monitoring by citizens - 2: A second public assembly was organized in collaboration with the Procida municipal administration to select volunteers for project phase 2 from July 2016 to September 2016. We successfully involved 79 families to allow deployment of 101 ovitraps on their private properties all over the island. A total of 40811 eggs were collected during two weeks in July and two weeks in September 2016.

8. Passive mosquito monitoring by citizens: We utilized the mobile application ZanzaMapp (2019) developed at the University of Rome La Sapienza, to involve citizen as well as tourists in the passive monitoring of mosquitoes. An entomological survey was performed on the island at the same time to validate the data obtained by the citizens and tourists using the ZanzaMapp app (September 2016). 

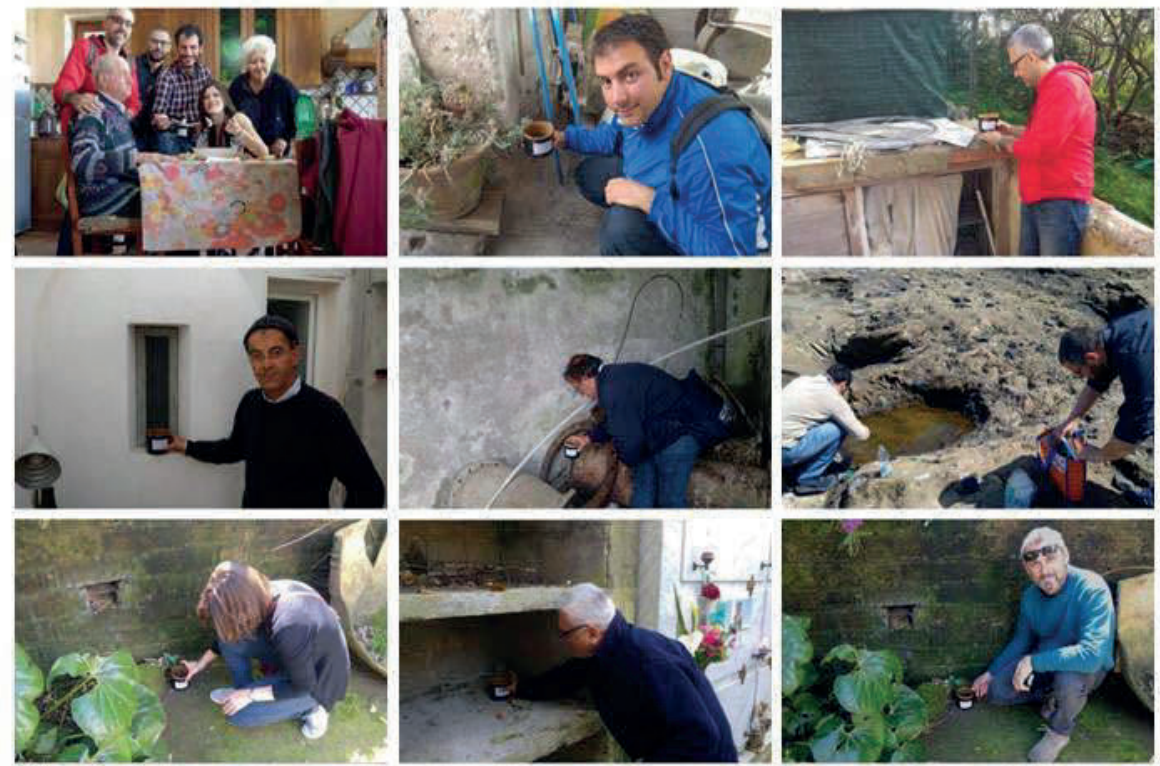

Figure 2. Volunteers and researchers during Aedes albopictus monitoring phase 1 on Procida island.

9. Active mosquito monitoring by citizens - 3: A third public assembly was organized with citizens in collaboration with the Procida municipal administration to select volunteers for project phase 3. We successfully involved 12 families to allow placement in their gardens of ovitraps, CDClight traps, Biogents BG-Sentinel traps, sticky traps and human landing catches stations to set up optimal conditions to perform a mark-releaserecapture test in an area of the island selected as a potential SIT testing site (September 2017).

10. School involvement: Procida primary and secondary school students have been involved in a collaborative didactic project aimed at the diffusion of knowledge about Asian tiger mosquito. Students were asked to actively participate in a sanitation campaign to reduce Ae. albopictus larval breeding sites in their home properties (October 2017-June 2018).

11. Active mosquito monitoring by citizens - 4: Ten volunteers were selected for the management of a permanent mosquito monitoring network on the island using 20 ovitrap and 20 low-cost weather stations (April 2018-May 2019). Volunteers collected eggs weekly and eggs were counted using stereomicroscopes. Data resulting from counting were uploaded by students in an ad-hoc online database. The collected eggs were sent monthly to the University of Naples Federico II to validate the counts. 


\section{CONCLUSIONS}

Mosquitoes are considered among the deadliest animals on earth and invasive mosquito species, such as the Asian tiger mosquito, represent a special concern in view of their ability to adapt to new habitats world-wide and to transmit several serious diseases to humans. Managing the public health threat represented by mosquitoes is not only a matter of vector control but also of influencing or modifying public behaviour.

The involvement of civil society in research projects, the so-called citizen science, represents an interesting opportunity in this context to mobilize support, with the possible reductions in working costs, as well as increasing capillarity in the target area. At the same time, it could increase public awareness about the mosquito problem and about virtuous control efforts that could limit mosquito spread (Fig. 2).

Procida Island has a unique combination of key features that makes it an ideal "open-space laboratory" to study the effectiveness of surveillance and suppression methods, including the SIT and similar tools as part of an AW-IVM approach against Ae. albopictus. The project on Procida Island began as a pilot study in 2015, with a limited group of volunteers and resources. We successfully involved the Procida administration and about 200 local inhabitants.

Through the action of a dedicated team of full-time professionals and the participation of an increased numbers of volunteers, we started the collection of baseline data about the spatial and temporal population dynamics of Ae. albopictus.

We aim in the near future to utilize these collected data, the know-how obtained, and the network of established interactions with citizen and the local municipal administration, to extend the approach to the whole territory of the island. Our long-term and most ambitious objective is to obtain a consistent suppression of the population of this invasive species on Procida to help the local economy, which is mainly based on tourism. Furthermore, we aim to promote the application of a SIT-based mosquito integrated management approach, empowered by active community engagement and participation, on other islands of Campania Region (Ischia and Capri), and eventually on the mainland.

\section{ACKNOWLEDGEMENTS}

This work was supported by a special grant by the Rector of University of Naples Federico II, Prof. Gaetano Manfredi.

We are deeply grateful for the invaluable support received from the Procida Major Raimondo Ambrosino and the municipal counsellors Rossella Lauro and Titta Lubrano. 
We are very grateful to the Procida volunteers Costantino D'Antonio, Davide Zeccolella, Luigi “Corecane” D’Orio, Cesare Buoninconti, Amedeo Schiano, Michele Meglio, Alberto Salvemini, Max Noviello, Anna and Antonio Amalfitano, Emanuela Coppola, Biagio and Isa Coppola, Angela and Pasquale Lubrano, Claudia Riccio and Antonietta Pagano, who shared their time to support this project.

We thank Nella Scotto for the assistance during the survey carried out on the island.

We greatly thank Prof. Luciano Gaudio for his support and the following students of the University of Naples Federico II involved in this project: Luca Iesu, Brunella Bozzi, Angela Meccariello, Rita Colonna and Antonio Marino. We thank Marco Di Luca and Francesco Severini, Istituto Superiore di Sanità, Rome, Italy, for the help in the identification of Culex mosquito species.

We thank all the Procida citizens and tourist accommodations (Hotel Riviera, Hotel La Torre, Hotel Savoia, Camping Punta Serra, Camping Vivara) that granted us access to their private properties for the mosquito monitoring activities. We thank the Comitato di Gestione Isola di Vivara for the authorization to access the reserve.

\section{REFERENCES}

Albieri, A., M. Carrieri, P. Angelini, F. Baldacchini, C. Venturelli, S. M. Zeo, and R. Bellini, R. 2010. Quantitative monitoring of Aedes albopictus in Emilia-Romagna, Northern Italy: Cluster investigation and geostatistical analysis. Bulletin of Insectology 63: 209-216.

Balestrino, F., A. Puggioli, R. Bellini, D. Petric, and J. R. L. Gilles. 2014. Mass production cage for Aedes albopictus (Diptera: Culicidae). Journal of Medical Entomology 51: 155-163.

Barceló, C., M. Bengoa, M. Monerris, R. Molina, S. Delacour-Estrella, J. Lucientes, and M. A. Miranda. 2015. First record of Aedes albopictus (Skuse, 1894) (Diptera; Culicidae) from Minorca (Balearic Islands, Spain). Journal of the European Mosquito Control Association 33: 1 4.

Bellini, R., M. Calvitti, A. Medici, M. Carrieri, G. Celli, and S. Maini. 2007. Use of the Sterile Insect Technique against Aedes albopictus in Italy: First results of a pilot trial, pp. 505-515. In M. J. B. Vreysen, A. S. Robinson, and J. Hendrichs (eds.), Area-wide control of insect pests: From research to field implementation. Springer, Dordrecht, The Netherlands.

Bellini, R., A. Medici, A. Puggioli, F. Balestrino, and M. Carrieri. 2013. Pilot field trials with Aedes albopictus irradiated sterile males in Italian urban areas. Journal of Medical Entomology 50: $317-325$.

Bengoa, M., S. Delacour-Estrella, C. Barceló, C. Paredes-Esquivel, M. Leza, J. Lucientes, R. Molina, and M. A. Miranda. 2016. First record of Aedes albopictus (Skuse, 1894) (Diptera; Culicidae) from Minorca (Balearic Islands, Spain). Journal of the European Mosquito Control Association 34: 5-9.

Bonizzoni, M., W. A. Dunn, C. L. Campbell, K. E. Olson, O. Marinotti, and A. A. James. 2012. Complex modulation of the Aedes aegypti transcriptome in response to dengue virus infection. PLoS One 7(11): e50512.

Bonney, R., J. L. Shirk, T. B. Phillips, A. Wiggins, H. L. Ballard, A. J. Miller-Rushing, and J. K. Parrish. 2014. Next steps for citizen science. Science (80) 343: 1436-1437.

Bourtzis, K., R. S. Lees, J. Hendrichs, and M. J. B. Vreysen. 2016. More than one rabbit out of the hat: Radiation, transgenic and symbiont-based approaches for sustainable management of mosquito and tsetse fly populations. Acta Tropica 157: 115-130.

Caminade, C., J. M. Medlock, E. Ducheyne, K. M. McIntyre, S. Leach, M. Baylis, and A. P. Morse. 2012. Suitability of European climate for the Asian tiger mosquito Aedes albopictus: Recent trends and future scenarios. Journal of The Royal Society Interface 9: 2708-2717. 
Cancrini, G., A. Frangipane Di Regalbono, I. Ricci, C. Tessarin, S. Gabrielli, and M. Pietrobelli. 2003. Aedes albopictus is a natural vector of Dirofilaria immitis in Italy. Veterinary Parasitology 118: 195-202.

Cirio, U. 1975. The Procida medfly pilot experiment: Status of the medfly control after two years of sterile-insect releases, pp. 39-49. In Panel and Research Co-ordination Meeting on the SterileMale Technique for Control of Fruit Flies, 12 Nov 1973. FAO/IAEA, Vienna, Austria.

Cirio, U., M. Capparella, and A. P. Economopoulus. 1987. Control of medfly (Ceratitis capitata Wied.) by releasing a mass-reared genetic sexing strain, pp. 515-522. In A. P. Economopoulos (ed.), Fruit flies. Elsevier, Amsterdam, The Netherlands.

Cunze, S., J. Kochmann, L. K. Koch, and S. Klimpel. 2016. Aedes albopictus and its environmental limits in Europe. PLoS One 11(9): e0162116.

D'Antonio, C., and D. Zeccolella. 2007. "Attuali conoscenze della fauna terrestre della Riserva Naturale di Stato Isola de Vivara" In "Vivara. Viaggio alla scoperta della fauna terrestre di una piccola isola del Mediterraneo". Casa Editrice Autorinediti, Napoli, Italia.

Di Luca, M., F. Severini, L. Toma, D. Boccolini, R. Romi, M. E. Remoli, M. Sabbatucci, C. Rizzo, G. Venturi, G. Rezza, and C. Fortuna. 2016. Experimental studies of susceptibility of Italian Aedes albopictus to Zika virus. Eurosurveillance 21(18): 30223.

Dickinson, J. L., J. Shirk, D. Bonter, R. Bonney, R. L. Crain, J. Martin, T. Phillips, and K. Purcell. 2012. The current state of citizen science as a tool for ecological research and public engagement. Frontiers in Ecology and the Environment 10(6): 291-297.

Dyck, V. A., J. Hendrichs, and A. Robinson (eds.). 2021. Sterile Insect Technique - Principles and practice in Area-wide Integrated Pest Management. Second Edition. CRC Press, Boca Raton, Florida, USA. 1200 pp.

(ECDC) European Centre for Disease Prevention and Control. 2018a. Aedes albopictus - current known distribution in Europe, June 2018.

(ECDC) European Centre for Disease Prevention and Control. 2018b. Mosquito-borne diseases: An emerging threat.

Fischer, D., S. M. Thomas, F. Niemitz, B. Reineking, and C. Beierkuhnlein. 2011. Projection of climatic suitability for Aedes albopictus Skuse (Culicidae) in Europe under climate change conditions. Global and Planetary Change 78: 54-64.

Gasperi, G., R. Bellini, A. R. Malacrida, A. Crisanti, M. Dottori, and S. Aksoy. 2012. A new threat looming over the Mediterranean basin: Emergence of viral diseases transmitted by Aedes albopictus mosquitoes. PLoS Neglected Tropical Diseases 6(9): e1836.

Gatt, P., J. C. Deeming, and F. Schaffner. 2009. First record of Aedes (Stegomyia) albopictus (Skuse) (Diptera: Culicidae) in Malta. European Mosquito Bulletin 27: 56-64.

Gilles, J. R. L., M. F. Schetelig, F. Scolari, F. Marec, M. L. Capurro, G. Franz, and K. Bourtzis. 2014. Towards mosquito sterile insect technique programmes: Exploring genetic, molecular, mechanical and behavioural methods of sex separation in mosquitoes. Acta Tropica 132 (Suppl.): S178-187.

Grard, G., M. Caron, I. M. Mombo, D. Nkoghe, S. Mboui Ondo, D. Jiolle, D. Fontenille, C. Paupy, and E. M. Leroy. 2014. Zika virus in Gabon (Central Africa) - 2007: A new threat from Aedes albopictus? PLoS Neglected Tropical Diseases 8(2): e2681.

Heitmann, A., S. Jansen, R. Lühken, M. Leggewie, M. Badusche, B. Pluskota, N. Becker, O. Vapalahti, J. Schmidt-Chanasit, and E. Tannich. 2017. Experimental transmission of zika virus by mosquitoes from central Europe. Eurosurveillance 22(2): 30437.

Jordan, R. C., A. E. Sorensen, and S. Ladeau. 2017. Citizen science as a tool for mosquito control. Journal of the American Mosquito Control Association 33(3): 241-245.

Kampen, H., J. M. Medlock, A. Vaux, C. Koenraadt, A. van Vliet, F. Bartumeus, A. Oltra, C. A. Sousa, S. Chouin, and D. Werner. 2015. Approaches to passive mosquito surveillance in the EU. Parasites and Vectors 8(1): 9.

Lees, R. S., J. R. Gilles, J. Hendrichs, M. J. B. Vreysen, and K. Bourtzis. 2015. Back to the future: The Sterile Insect Technique against mosquito disease vectors. Current Opinion in Insect Science 10: 156-162.

Li, Y., X. Su, G. Zhou, H. Zhang, S. Puthiyakunnon, S. Shuai, S. Cai, J. Gu, X. Zhou, G. Yan, and X. G. Chen. 2016. Comparative evaluation of the efficiency of the BG-Sentinel trap, CDC light trap and Mosquito-oviposition trap for the surveillance of vector mosquitoes. Parasites and Vectors 9: 446. 
Manica, M., F. Filipponi, A. D’Alessandro, A. Screti, M. Neteler, R. Rosà, A. Solimini, A. della Torre, and B. Caputo. 2016. Spatial and temporal hot spots of Aedes albopictus abundance inside and outside a South European metropolitan area. PLoS Neglected Tropical Diseases 10(6): e0004758.

Marini, F., B. Caputo, M. Pombi, G. Tarsitani, and A. Della Torre. 2010. Study of Aedes albopictus dispersal in Rome, Italy, using sticky traps in mark-release-recapture experiments. Medical and Veterinary Entomology 24: 361-368.

Medlock, J. M., K. M. Hansford, V. Versteirt, B. Cull, H. Kampen, D. Fontenille, G. Hendrickx, H. Zeller, W. Van Bortel, and F. Schaffner. 2015. An entomological review of invasive mosquitoes in Europe. Bulletin of Entomological Research 105: 637-663.

Miquel, M., R. Del Río, D. Borràs, C. Barceló, C. Paredes-Esquivel, J. Lucientes, and M. A. Miranda. 2013. First detection of Aedes albopictus (Diptera: Culicidae) in the Balearic Islands (Spain) and assessment of its establishment according to the ECDC guidelines. Journal of the European Mosquito Control Association 31: 8-11.

Mosquito Alert. 2019. Ciencia ciudadana para investigar y controlar mosquitos transmisores de enfermedades. Spain.

MosquitoWEB. 2019. Portugal. www.mosquitoweb.pt

(MRS) Mosquito Recording Scheme. 2019. Biological Records Centre. Public Health England.

Muggenradar. 2019. Meld mate van muggenoverlast. Nature Today, The Netherlands.

Mückenatlas. 2019. Deutschland kartiert die Stechmücken. Germany.

Palmer, J. R. B., A. Oltra, F. Collantes, J. A. Delgado, J. Lucientes, S. Delacour, M. Bengoa, R. Eritja, and F. Bartumeus. 2017. Citizen science provides a reliable and scalable tool to track disease-carrying mosquitoes. Nature Communications 2017 Oct 24, 8(1): 916.

Pietrobelli, M. 2008. Importance of Aedes albopictus in veterinary medicine. Parassitologia 50: 113 115.

Reisen, W. K., R. P. Meyer, R. F. Cummings, and O. Delgado. 2000. Effects of trap design and $\mathrm{CO}_{2}$ presentation on the measurement of adult mosquito abundance using Centers for Disease Control-style miniature light traps. Journal of the American Mosquito Control Association 16: $13-18$.

Robinson, A. S. 2002. Genetic sexing strains in medfly, Ceratitis capitata, Sterile Insect Technique programmes. Genetica 116: 5-13.

Roiz, D., R. Eritja, R. Molina, R. Melero-Alcibar, and J. Lucientes. 2008. Initial distribution assessment of Aedes albopictus (Diptera: Culicidae) in the Barcelona, Spain, area. Journal of Medical Entomology 45: 347-352.

Romi, R., S. D'Avola, D. Todaro, L. Toma, F. Severini, A. Stancanelli, F. Antoci, F. La Russa, D. Boccolini, S. Casano, S. D. Sotera, E. Carraffa, F. Schaffner, M. Di Luca, and A. Torina. 2016. Aedes albopictus (Skuse, 1894) in the southernmost limit of Europe: First record in Lampedusa, Linosa and Pantelleria islands and current distribution in Sicily, Italy, pp. 185. In Proceedings of the 29th SOIPA Congress, June 21-24, 2016, Bari, Italy.

Sabatini, A., V. Raineri, G. Trovato, and M. Coluzzi. 1990. Aedes albopictus in Italia e possibile diffusione della specie nell'area mediterranea. Parassitologia 32: 301-304.

Saridaki, A. and K. Bourtzis. 2010. Wolbachia: More than just a bug in insect genitals. Current Opinion in Microbiology 13: 67-72.

Schaffner, F., G. Angel, B. Geoffroy, J. P. Hervy, A. Rhaiem, and J. Brunhes. 2001. The mosquitoes of Europe/Les moustiques d'Europe. Programme d'identification et d'enseignement. IRD Éditions et EID Méditerranée (CD ROM). Montpellier, France.

Sokhna, C., M. O. Ndiath, and C. Rogier. 2013. The changes in mosquito vector behaviour and the emerging resistance to insecticides will challenge the decline of malaria. Clinical Microbiology and Infection 19(10): 902-907.

Toma, L., F. Toma, G. Pampiglione, M. Goffredo, F. Severini, and M. Di Luca. 2017. First record of Aedes albopictus (Skuse, 1894) (Diptera; Culicidae) from three islands in the Tyrrhenian Sea (Italy). Journal of the European Mosquito Control Association 35: 25-28.

Valerio, L., F. Marini, G. Bongiorno, L. Facchinelli, M. Pombi, B. Caputo, M. Maroli, and A. della Torre. 2010. Host-feeding patterns of Aedes albopictus (Diptera: Culicidae) in urban and rural contexts within Rome Province, Italy. Vector-Borne Zoonotic Diseases 10: 291-294. 
Venturi, G., M. Di Luca, C. Fortuna, M. E. Remoli, F. Riccardo, F. Severini, L. Toma, M. Del Manso, E. Benedetti, M. G. Caporali, A. Amendola, C. Fiorentini, C. De Liberato, R. Giammattei, R. Romi, P. Pezzotti, G. Rezza, and C. Rizzo. 2017. Detection of a chikungunya outbreak in Central Italy, August to September 2017. Eurosurveillance 22(39): 11-14.

Vontas, J., E. Kioulos, N. Pavlidi, E. Morou, A. della Torre, and H. Ranson. 2012. Insecticide resistance in the major dengue vectors Aedes albopictus and Aedes aegypti. Pesticide Biochemistry and Physiology 104: 126-131.

(WHO) World Health Organization. 2019. Vector-borne diseases.

ZanzaMapp. 2019. Italy. http://www.zanzamapp.it/

Zeller, H., L. Marrama, B. Sudre, W. Van Bortel, and E. Warns-Petita. 2013. Mosquito-borne disease surveillance by the European Centre for Disease Prevention and Control (ECDC). Clinical Microbiology and Infection 19(8): 693-698. 